\title{
PRINSIP CABOTAGE DALAM INDUSTRI PENERBANGAN INDONESIA DI ERA ASIAN SINGLE AVIATION MARKET 2015
}

\author{
Adi Kusumaningrum \\ Fakultas Hukum Universitas Brawijaya Malang \\ (adi.kusumaningrum@gmail.com)
}

\begin{abstract}
ASEAN Single Aviation Market 2015, is a policy that has been agreed by all ASEAN member countries. This agreement called ASEAN Multilateral Agreement on Air Services (ASEAN MAAS) and was signed on May 20, 2009 in Manila, Philippines. Despite the many advantages and potential benefits from the open sky policy, the government should be aware of the threat in the ASEAN aviation market, such as the market share of domestic flights among domestic and foreign airline in this region. Futhermore, control foreign investment in the field of air transport in Indonesia is weak, thus opening the possibility of smuggling investment law through the establishment of an Indonesian legal entity. Cabotage principle objective is maintaining and protecting the political and economic interests of the country. Application of the principle of cabotage could be operationally flexible, as long as the country's strategic interests is maintained and protected. Aviation services in Indonesia is currently considered to have violated the principle of cabotage.
\end{abstract}

Keyword: cabotage, aviation, market, ASEAN

\begin{abstract}
Abstrak
Pasar tunggal penerbangan ASEAN (ASEAN Single Aviation Market) pada tahun 2015, merupakan kebijakan yang telah disepakati oleh seluruh negara anggota ASEAN yang tertuang dalam ASEAN Multilateral Agreement on Air Services (ASEAN MAAS) dan telah ditandatangani pada tanggal 20 Mei 2009 di Manila, Filipina. Dalam menghadapi ASEAN Single Aviation Market 2015, selain memperhatikan potensi keuntungan yang dapat diperoleh dari kebijakan open sky tersebut, pemerintah harus mewaspadai peluang ancaman perebutan pangsa pasar penerbangan di wilayah ASEAN juga pangsa pasar penerbangan domestik. alah satu faktor yang dapat mengancam Indonesia adalah lemahnya pengawasan (direct or indirect) investment bidang angkutan udara, sehingga kemungkinan terjadi penyelundupan hukum investasi, yang akhirnya pasar nasional dikuasai asing melalui badan hukum Indonesia yang dibentuknya (cabotage terselubung). Prinsip cabotage diterapkan secara umum di seluruh dunia dengan tujuan menjaga dan melindungi kepentingan politik dan ekonomi negara yang bersangkutan. Penerapan prinsip cabotage secara operasional bisa bersifat fleksibel, selama kepentingan strategis negara tersebut tetap terjaga dan terlindungi. Pelayanan penerbangan di Indonesia saat ini dianggap sudah melanggar prinsip cabotage.
\end{abstract}

Kata Kunci: cabotage, penerbangan, pasar, ASEAN

\section{Latar Belakang}

Pada tahun 2015 seluruh negara-negara yang tergabung dalam ASEAN ${ }^{1}$ diharapkan telah memiliki bandar udara internasional dan membuka seluruh wilayah ruang udaranya. Hal tersebut dalam rangka mewujudkan pasar tunggal penerbangan ASEAN (ASEAN Single Aviation Market) pada tahun 2015. Kebijakan regional tersebut

1 ASEAN terdiri dari 10 negara antara lain Brunei Darussalam, Indonesia, Kamboja, Laos, Malaysia, Myanmar, Philipina, Singapura, Thailand, dan Vietnam. 
telah disepakati oleh seluruh negara anggota ASEAN yang tertuang dalam ASEAN Multilateral Agreement on Air Services (ASEAN MAAS) dan telah ditandatangani pada tanggal 20 Mei 2009 di Manila, Filipina.

Kesepakatan Multilateral ASEAN di bidang pelayanan udara tersebut dilandasi oleh lahirnya Deklarasi ASEAN (Bali Concord II) pada KTT ASEAN ke-9 bulan Oktober tahun 2003 di Bali, Indonesia. Deklarasi tersebut menghasilkan suatu sasaran ekonomi regional dengan membentuk Komunitas ASEAN 2015 yang berlandaskan 3 pilar yakni Komunitas Keamanan ASEAN (ASEAN Security Community), Komunitas Ekonomi ASEAN (ASEAN Economic Community), dan Komunitas Sosial-Budaya ASEAN (ASEAN Socio-Cultural Community). Dan dalam Komunitas Ekonomi ASEAN salah satu tujuannya adalah Air Travel Integration atau integrasi dalam bidang pelayanan udara. Kemudian hal tersebut juga ditegaskan dalam ASEAN Framework Agreement for The Integration of Priority Sectors (AFAIPS) yang juga telah disepakati pada KTT ASEAN ke-10 tanggal 29 November 2004 di Vientine, Laos yang merupakan suatu kesepakatan kerangka kerja Negara-negara ASEAN untuk mengintegrasikan beberapa sektor yang diprioritaskan atau dianggap penting. Dan jasa angkutan udara merupakan salah satu dari 11 sektor-sektor prioritas yang ada. ${ }^{2}$ Indonesia sendiri telah mengesahkan AFAIPS melalui Peraturan Presiden Nomor 25 Tahun 2009.

ASEAN MAAS secara umum mengatur mengenai liberalisasi di bidang jasa angkutan udara khususnya jasa angkutan udara penumpang yang diwujudkan dalam bentuk ASEAN Open Sky
Policy pada tahun 2015. Implementasi ASEAN open sky ini dilakukan secara bertahap yang tahapan-tahapannya ditentukan dalam protokolprotokol yang terdapat dalam ASEAN MAAS. Kebijakan langit terbuka ini telah diatur pula dalam Pasal 90 Undang-Undang Nomor 1 Tahun 2009 tentang Penerbangan yang menetapkan bahwa pembukaan pasar angkutan udara menuju ruang udara terbuka tanpa batasan hak angkut udara (open sky) dari dan ke Indonesia untuk perusahaan angkutan udara niaga asing dilaksanakan secara bertahap berdasarkan perjanjian bilateral atau multilateral serta harus dibuat sesuai dengan ketentuan peraturan perundang-undangan dan mempertimbangkan kepentingan nasional berdasarkan prinsip keadilan (fairness) dan timbal balik (resiprocity).

Indonesia adalah negara kepulauan yang terdiri atas berbagai gugusan pulau ${ }^{3}$. Selain itu, jumlah penduduk Indonesia juga sangat besar ${ }^{4}$. Dua faktor tersebut adalah hal dasar yang menjanjikan prospek bisnis penerbangan di Indonesia ke depan. Dengan jumlah penduduk yang besar dan letak geografis yang terpisah antara kepulauan, maka potensi dari bisnis penerbangan masih terbuka lebar tidak saja untuk industri dalam tapi juga luar negeri. Disamping itu, Indonesia yang memiliki 27 (dua puluh tujuh) bandara internasional ${ }^{5}$, yang memberikan peluang besar bagi negara ASEAN lain untuk meraup keuntungan melalui kebijakan ASEAN open sky. Apabila dibandingkan dengan Singapura yang hanya punya 1 (satu) bandara dan Malaysia yang punya 6 (enam) bandara, maka komposisi yang dimiliki Indonesia jelas tidak sebanding dengan kedua negara tersebut ${ }^{6}$.

2 Sektor-sektor prioritas yang akan diintegrasikan adalah produk berbasis agro, angkutan udara, otomotif, e-ASEAN, elektronik, perikanan, kesehatan, produk berbasis karet, tekstil dan pakaian, pariwisata, dan produk berbasis kayu.

3 Indonesia merupakan negara kepulauan yang berbentuk republik, terletak di kawasan Asia Tenggara. Indonesia memiliki lebih kurang 17.000 buah pulau dengan luas daratan $1.922 .570 \mathrm{~km} 2$ dan luas perairan $3.257 .483 \mathrm{~km} 2$ Berdasarkan posisi geografisnya, negara Indonesia memiliki batas-batas: Utara - Negara Malaysia, Singapura, Filipina, Laut Cina Selatan. Selatan - Negara Australia, Samudera Hindia. Barat - Samudera Hindia. Timur - Negara Papua Nugini, Timor Leste, Samudera Pasifik.

4 Indonesia mempunyai 230 juta penduduk. Dari jumlah sebanyak itu baru 68 juta yang tercatat menjadi penumpang penerbangan udara domestik dan internasional sepanjang 2011, atau hanya 17 juta orang yang murni melakukan penerbangan. Berdasarkan studi yang dilakukan Ketua Forum Penerbangan Masyarakat Transportasi Indonesia (MTI) Suharto, rata-rata terbang satu orang dalam 1 tahun sebanyak empat kali. Jadi, kalau tercatat jumlah penumpang udara 2011 sebanyak 68 juta, domestik dan internasional, berarti yang murni terbang adalah 17 juta, atau hanya 7\% dari total penduduk Indonesia. Pada Januari 2012, Badan Pusat Statistik mencatat jumlah penumpang pesawat udara domestik mencapai 4,38 juta dan internasional 930.700 orang. Indonesia Air Asia, maskapai yang menempati posisi tertinggi untuk perolehan penumpang internasional sepanjang 2011 yakni 3,39 juta penumpang dan pangsa pasar 41,56\%, akan menambah armada sebanyak lima unit pada tahun ini, dari posisi saat ini mengoperasikan 21 pesawat.

5 Bandara-bandara internasional Indonesia tersebut terletak di kota Sabang, Banda Aceh, Medan, Pekan Baru, Batam, Tanjung Pinang, Padang, Palembang, Jakarta, Bandung, Yogjakarta, Solo, Surabaya, Denpasar, Pontianak, Balikpapan, Tarakan, Makassar, Manado, Mataram, Kupang, Ambon, Biak, Jayapura dan Merauke.

6 Kementerian Perhubungan membuka peluang bagi maskapai asing (di Asia Tenggara) bebas untuk melakukan penerbangan ke lima bandara di Indonesia. Kelima bandara tersebut yaitu Bandara Soekarno-Hatta (Jakarta), Bandara Kuala Namu (Medan),Bandara Ngurah Rai (Denpasar), Bandara Juanda (Surabaya), dan Bandara Sultan Hasanuddin (Makasar). Padahal, negara Asia Tenggara lain seperti Malaysia dan Singapura masing-masing hanya memberikan satu pilihan bandara untuk dikunjungi maskapai penerbangan nasional 
Untuk itu, dalam menghadapi ASEAN Single Aviation Market 2015, selain memperhatikan potensi keuntungan yang dapat diperoleh dengan kebijakan open sky ini, pemerintah harus mewaspadai peluang ancaman perebutan pangsa pasar penerbangan di wilayah ASEAN juga pangsa pasar penerbangan domestik. Salah satu ancaman perebutan pangsa pasar penerbangan Indonesia adalah deregulasi terhadap penerapan prinsip cabotage. Lemahnya pengawasan (direct or indirect) investment bidang angkutan udara, sehingga membuka peluang terjadi penyelundupan hukum investasi, yang akhirnya pasar nasional dikuasai asing melalui badan hukum Indonesia yang dibentuknya (cabotage terselubung). Di Indonesia ini hampir semua penerbangan logistik itu dikendalikan oleh swasta atau penerbangan asing. Pelayanan penerbangan di Indonesia tersebut dianggap sudah melanggar prinsip cabotage. Saat ini, maskapai penerbangan Asing dan Swasta dapat melayani penerbangan rute Penang (Malaysia) - Denpasar (Indonesia) - Makasar (Indonesia) ${ }^{7}$. Komisi VI DPR RI meminta pemerintah menerapkan kebijakan prinsip cabotage (kebijakan menggunakan bendera Indonesia pada armada yang beroperasi di Indonesia) pada transportasi udara ${ }^{8}$. Komisi VI DPR RI menyatakan bahwa Indonesia belum siap open sky, apalagi agresi maskapai asing yang bertransformasi memakai nama Indonesia sangat gencar. Dari segi kebijakan, Indonesia dinilai terlalu membebaskan rute penerbangan, maskapai asing yang masuk ke Indonesia pun hanya kelas penerbangan murah (low cost carrier/LCC), bukan penerbangan kelas premium. Akibatnya, secara ekonomis, penumpang Indonesia lebih memilih layanan penerbangan murah maskapai asing. Berikut tabel perolehan jumlah penumpang penerbangan domestik 2011 (tabel 1) dan penerbangan internasional 2011 (tabel 2).
Tabel 1: perolehan jumlah penumpang penerbangan domestik 2011

\begin{tabular}{|c|l|l|l|}
\hline No & Maskapai & Penumpang & $\begin{array}{l}\text { Pangsa } \\
\text { Pasar(\%) }\end{array}$ \\
\hline 1 & Lion Air & 24,97 (juta) & 41,59 \\
\hline 2 & $\begin{array}{l}\text { Garuda Indo- } \\
\text { nesia }\end{array}$ & 18,70 (juta) & 22,82 \\
\hline 3 & Sriwijaya Air & 7,38 (juta) & 12,30 \\
\hline 4 & Batavia Air & 6,75 (juta) & 11,25 \\
\hline 5 & Merpati & 2,18 (juta) & 3,64 \\
\hline 6 & Wings Air & 1,98 (juta) & 3,32 \\
\hline 7 & $\begin{array}{l}\text { Indonesia Air } \\
\text { Asia }\end{array}$ & 1,30 (juta) & 2,18 \\
\hline 8 & $\begin{array}{l}\text { Trigana Air } \\
\text { Service }\end{array}$ & 727.857 & 1,21 \\
\hline 9 & $\begin{array}{l}\text { Kalstar Avia- } \\
\text { tion }\end{array}$ & 579.196 & 0,96 \\
\hline 10 & $\begin{array}{l}\text { Travel Express } \\
\text { Air }\end{array}$ & 316.000 & 0,55 \\
\hline & \multicolumn{2}{|l|}{ Total } & 60.039 .293 \\
\hline
\end{tabular}

Sumber: Kementerian Perhubungan, Maret 2012.

Tabel 2: perolehan jumah penumpang penerbangan internasional 2011

\begin{tabular}{|c|l|l|l|}
\hline No & Maskapai & Penumpang & $\begin{array}{l}\text { Pangsa } \\
\text { Pasar(\%) }\end{array}$ \\
\hline 1 & $\begin{array}{l}\text { Indonesia Air } \\
\text { Asia }\end{array}$ & 3,39 (juta) & 41,56 \\
\hline 2 & $\begin{array}{l}\text { Garuda Indo- } \\
\text { nesia }\end{array}$ & 3,10 (juta) & 38,03 \\
\hline 3 & Lion Airlines & 962.608 & 11,90 \\
\hline 4 & Batavia Air & 292.260 & 3,59 \\
\hline 5 & Sriwijaya Air & 183.800 & 2,23 \\
\hline 6 & Wings Air & 138.414 & 1,76 \\
\hline 7 & $\begin{array}{l}\text { Merpati } \\
\text { Nusantara }\end{array}$ & 86.104 & 1,06 \\
\hline 8 & $\begin{array}{l}\text { Kalstar Avia- } \\
\text { tion }\end{array}$ & 0 & \multicolumn{2}{|l}{} \\
\hline & \multicolumn{2}{|l}{ Total } & 8.152 .133 \\
\hline
\end{tabular}

Sumber: Kementerian Perhubungan, Maret 2012.

7 Penerbangan RI Diminta Terapkan Asas Cabotage, http://www.inilah.com/read/detail/1646272/penerbangan. diakses pada tanggal 20 Maret 2012.

8 Kebijakan Open Sky di Indonesia, DPR minta pemerintah buat cabotage versi udara untuk tangkis open sky, http://nasional.kontan.co.id/ news/dpr-minta-pemerintah-buat-cabotage-versi-udara-untuk-tangkis-open-sky-1/2011/06/27. diakses pada tanggal 20 Maret 2012. 
Dari table 1 dan 2 tersebut diatas, dapat diketahui bahwa Lion Air mendapatkan pangsa pasar tertinggi untuk penumpang penerbangan domestic yakni $41,59 \%$. Adapun Indonesia Air Asia, yang sahamnya dimiliki maskapai penerbangan Malaysia, menempati posisi tertinggi untuk perolehan penumpang internasional sepanjang 2011 yakni 3,39 juta penumpang dan pangsa pasar $41,56 \%$.

\section{Prinsip Kedaulatan Penuh Dan Ekslusif Di Ruang Udara}

Kedaulatan Negara Indonesia atas wilayah udaranya ditegaskan dalam Pasal 5 UndangUndang Nomor 1 Tahun 2009 tentang Penerbangan yang menyebutkan bahwa: Negara Kesatuan Republik Indonesia berdaulat penuh dan eksklusif atas wilayah Republik Indonesia. Dalam penjelasan pasal tersebut dijelaskan bahwa sebagai negara berdaulat, Republik Indonesia memiliki kedaulatan penuh dan utuh di wilayah udara Republik Indonesia, sesuai dengan ketentuan Pasal 1 Konvensi Chicago 1944 tentang Penerbangan Sipil Internasional ${ }^{9}$. Ketentuan Pasal 1 Konvensi Chicago 1944 ini memberikan beberapa konsekuensi kedaulatan diudara bagi Negara kolong, diantaranya adalah: cabotage (pasal 7), kewenangan menetapkan daerah terlarang (pasal 8), penetapan bandar udara yang boleh didarati oleh penerbangan internasional (pasal 9), regulasi navigasi penerbangan (pasal 10), lalu lintas udara (pasal 11), dan ijin masuk Negara anggota (pasal 12). Prinsip kedaulatan atas wilayah udara secara penuh dan utuh tersebut juga diakui dalam Asean Multilateral Agreement on Air Services dengan ketentuan Pasal 1 ayat (1) yang menyatakan bahwa negara-negara peserta agreement telah meratifikasi Konvensi Chicago 1994 dan konvensi tersebut masih berlaku secara efektif bagi mereka.

Kedaulatan diruang udara Indonesia sebagai Negara kepulauan ditegaskan dalam Pasal 49 ayat 2 Konvensi Hukum Laut Internasional Tahun 1982 yang telah diratifikasi dengan Undang-Undang Nomor 17 Tahun 1985 Tentang Pengesahan United Nations Convention on the Law of the Sea. Pasal tersebut mengatur tentang status hukum perairan kepulauan, ruang udara diatas perairan kepulauan dan dasar laut serta tanah dibawahnya. Indonesia sebagai Negara kepulauan, maka kedaulatannya meliputi ruang udara diatas perairan kepulauan.

Selanjutnya dalam UU RI Nomor 1 Tahun 2009 tentang Penerbangan, Pasal 6 ditegaskan bahwa: Dalam rangka penyelenggaraan kedaulatan negara atas wilayah udara Negara Kesatuan Republik Indonesia, pemerintah melaksanakan wewenang dan tanggung jawab pengaturan ruang udara untuk kepentingan penerbangan, perekonomian nasional, pertahanan dan keamanan negara, sosial budaya, serta lingkungan udara.

Pasal 6 tersebut dilatarbelakangi oleh suatu pemikiran bahwa wilayah udara yang berupa ruang di atas wilayah daratan dan perairan RI merupakan kekayaan nasional sehingga harus dimanfaatkan bagi sebesar-besar kepentingan rakyat, bangsa, dan negara. Pasal 6 tersebut diatas, dijelaskan lebih lanjut oleh Pasal 7 ayat (1) yang menetapkan bahwa: Dalam rangka melaksanakan tanggungjawab sebagaimana pasal 6 , pemerintah menetapkan kawasan udara terlarang dan terbatas.

Dalam penjelasan pasal 7 (1) tersebut diatas dijelaskan bahwa kewenangan menetapkan kawasan udara terlarang dan terbatas merupakan kewenangan dari setiap negara berdaulat untuk mengatur penggunaan wilayah udaranya, dalam rangka keselamatan masyarakat luas, keselamatan penerbangan, perekonomian nasional, lingkungan hidup, serta pertahanan dan keamanan. Kemudian yang dimaksud dengan kawasan udara terlarang (prohibited area) adalah kawasan udara dengan pembatasan yang bersifat permanen dan menyeluruh bagi semua pesawat udara. Pembatasan hanya dapat ditetapkan di dalam wilayah udara Indonesia, sebagai contoh instalasi nuklir atau istana Presiden. Kawasan udara terbatas (restricted area) adalah kawasan udara dengan pembatasan bersifat tidak tetap dan hanya dapat digunakan untuk operasi penerbangan tertentu (pesawat udara TNI). Pada waktu tidak digunakan (tidak aktif), kawasan ini dapat digunakan untuk penerbangan sipil. Pembatasan dapat berupa pembatasan ketinggian dan hanya dapat ditetapkan di dalam wilayah udara Indonesia, misalnya instalasi atau kawasan militer. 
Dengan adanya kedaulatan yang mutlak dan penuh atas ruang udaranya, maka negara tersebut berhak mengatur dan mengelola ruang udaranya bebas dari intervensi negara lain. ${ }^{10}$ Ruang udara nasional mempunyai sifat yang tertutup, hal ini mengingat ruang udara yang merupakan media gerak bagi pesawat terbang sangat rawan terutama ditinjau dari sudut kepentingan pertahanan dan keamanan negara dibawahnya.

Aplikasi terhadap prinsip kedaulatan negara diudara yang utuh dan mutlak tersebut mengakibatkan tidak ada pesawat dari negara lain yang memasuki atau melalui wilayah udara negara lainnya tanpa seizin, persetujuan dari negara tersebut berapapun ketinggiannya. ${ }^{11}$

Kedaulatan negara di udara meskipun utuh dan penuh tidak dapat dikatakan sebagai kedaulatan yang absolut atau bebas dari segala aturan hukum yang memaksa (legibus soluta) berdasarkan Hukum Internasional. Dalam prakteknya tunduk tidak hanya terhadap kewajiban yang telah ditentukan didalam perjanjian internasional, tetapi juga tunduk terhadap aturan-aturan umum yang diterima sebagai hukum kebiasaan.

Sifat kedaulatan utuh dan penuh dari negara diruang udara nasionalnya sangat berbeda dengan sifat kedaulatan negara dilaut wilayah. Karena sifatnya yang demikian itu maka ruang udara nasional tidak dikenal hak lintas dari pihak asing seperti terdapat di laut teritorial. ${ }^{12} \mathrm{Hal}$ ini berarti pada dasarnya wilayah udara suatu negara tertutup bagi pesawat-pesawat negara lain. Penggunaan dan kontrol atas wilayah udaranya tersebut menjadi hak yang utuh dan penuh dari negara kolongnya, kondisi ini diperlukan untuk mencegah terjadinya pelanggaran wilayah udara yaitu suatu keadaan, dimana pesawat terbang suatu negara sipil atau militer memasuki wilayah udara negara lain tanpa ijin sebelumnya dari negara yang memasukinya. ${ }^{13}$

Sepanjang menyangkut hak penerbangan (traffic right), Konvensi Chicago 1944 membedakan antara penerbangan internasional tidak berjadwal (non schedule flight) dengan penerbangan internasional berjadwal (schedule flight). Dalam pasal 5 ayat (1) Konvensi
Chicago 1944 dijelaskan bahwa penerbangan internasional tidak berjadwal dapat dilakukan di Negara anggota lainnya, tanpa memperoleh izin terlebih dahulu. Sedangkan dalam ayat (2) diatur bahwa apabila pesawat terbang tersebut membawa penumpang, barang pos atau muatan yang dipungut bayaran selain daripada penerbangan berjadwal mempunyai hak untuk menaikkan dan menurunkan penumpang dan sebagainya, akan tetapi harus menaati peraturan-peraturan, syarat-syarat atau pembatasan-pembatasan yang ditentukan oleh Negara setempat. Berikut ketentuan dari Pasal 5 tersebut:

Each contracting State agrees that all aircraft of the other contracting States, being aircraft not engaged in scheduled international air services shall have the right, subject to the observance of the terms of this Convention, to make flights into or in transit non-stop across its territory and to make stops for non-traffic purposes without the necessity of obtaining prior permission, and subject to the right of the State flown over to require landing. Each contracting State nevertheless reserves the right, for reasons of safety of flight, to require aircraft desiring to proceed over regions which are inaccessible or without adequate air navigation facilities to follow prescribed routes, or to obtain special permission for such flights.

Such aircraft, if engaged in the carriage of passengers, cargo, or mail for remuneration or hire on other than scheduled international air services, shall also, subject to the provisions of Article 7, have the privilege of taking on or discharging passengers, cargo, or mail, subject to the right of any State where such embarkation or discharge takes place to impose such regulations, conditions or limitations as it may consider desirable.

Hak lintas diatur pula dalam pasal 6 yang mengatur penerbangan berjadwal (schedule flight) dan merupakan pembatasan terhadap kedaulatan negara atas ruang udara diatasnya, yang berbunyi sebagai berikut :

10 Ketentuan mengenai kedaulatan juga diatur dalam Pasal 2 Ayat (2) Konvensi Hukum Laut PBB 1982 yang telah diratifikasi Indonesia dengan Undang-Undang RI Nomor 17 tahun 1985, menentukan bahwa kedaulatan negara meliputi ruang udara di atas laut teritorial serta dasar laut dan tanah di wilayahnya.

11 Bin Cheng The Law of International Air Transport, London: The London Institute of World Affairs, 1962 , hlm. 122.

12 R.R Churchill dan A. V. Lowe, The Law of The Sea, third Edition, Manchester: Manchester University Press, 1999 , 76.

13 T. May Rudy, Hukum Internasional 2, Bandung: PT Refika Aditama, 2002, 32. 
No scheduled international air service may be operated over or into the territory of a contracting State, except with the special permission or other authorization of that State, and in accordance with the terms of such permission or authorization.

Pada prinsipnya, pasal 6 menetapkan bahwa pesawat asing yang melakukan penerbangan harus meminta izin terlebih dahulu kepada Negara kolong atau Negara mana tempat ia terbang. Hal ini dapat dipahami bahwa apabila ada penerbangan berjadwal tentu memungkinkan terjadinya persaingan dengan penerbangan nasional. Untuk mencegah hal ini diperlukan adanya persetujuan lebih dahulu.

Pembahasan

\section{CABOTAGE SEBAGAI KONSEKUENSI KEDAULATAN NEGARA DI RUANG UDARA}

\section{Pengaturan Prinsip Cabotage dalam Convensi Chicago 1944 dan UU RI Nomor 1 Tahun 2009 tentang Penerbangan.}

Usaha pemanfaatan ruang udara memang mewajibkan Indonesia untuk mengembangkan kekuatan Negara di ruang udara dengan semaksimal mungkin sehingga efektif dan dapat diandalkan. Angkutan udara adalah salah satu faktor penting dari kekuatan Negara di ruang udara yang tidak hanya berfungsi sebagai sarana komersial semata, tetapi juga sebagai sarana untuk mempersatukan bangsa dalam pengertian politis, sarana untuk membantu kelancaran efektifitas pemerintahan dan sarana untuk mendorong lajunya pembangunan. Pembangunan jalur komunikasi yang seluas mungkin antar Kepulauan Nusantara. ${ }^{14}$

Untuk dapat mewujudkan fungsi ini maka salah satu asas penting dalam hukum udara, khususnya angkutan udara adalah konsep cabotage. Konsep cabotage dalam hukum udara berasal dari pengertian yang sama yang tumbuh dalam hukum laut. Konsep ini sebagai salah satu bentuk manifestasi kedaulatan negara di udara secara penuh dan utuh serta pemanfaatannya bagi sebesar-besar kepentingan rakyat, bangsa, dan negara. Dalam hukum udara prinsip cabotage telah diterima dalam pasal
7 Konvensi Chicago 1944 yang berbunyi:

Each contracting State shall have the right to refuse permission to the aircraft of other contracting States to take on in its territory passengers, mail and cargo carried for remuneration or hire and destined for another point within its territory. Each contracting State undertakes not to enter into any arrangements which specifically grant any such privilege on an exclusive basis to any other State or an airline of any other State, and not to obtain any such exclusive privilege from any other State.

Dalam pasal tersebut ditetapkan bahwa setiap Negara peserta mempunyai hak untuk menolak memberikan izin kepada suatu pesawat udara milik Negara peserta lain, yang bermaksud mengambil penumpang, pos dan cargo, dengan mendapatkan bayaran atau sewa, dari satu tempat ke tempat lain di dalam wilayahnya. Pasal tersebut melarang setiap Negara peserta untuk memberikan secara khusus suatu privilege (cabotage) eksklusif kepada Negara peserta lain atau suatu perusahaan penerbangan milik Negara lain, dan menerima suatu privilege (cabotage) eksklusif semacam itu dari Negara lain. Prinsip cabotage ini tidak dapat dilepaskan dari prinsip bahwa suatu Negara mempunyai hak penuh atas wilayah di udara di atasnya, seperti tercantum dalam pasal 1 konvensi Chicago 1944.

Cabotage dalam hukum udara juga dikenal sebagai "the eight freedom", suatu hak yang dapat diperjanjikan atas kehendak Negara-negara peserta, yaitu hak untuk mengangkut traffic dari satu tempat ke tempat lain di dalam wilayah satu Negara $^{15}$. Sebagai contohnya adalah pengangkutan penumpang, barang, dan pos secara komersial dari Singapura, Jakarta, Denpasar dan Melbourne, maka porsi cabotage adalah ruas Jakarta-Denpasar. Ruas tersebut merupakan hak penerbangan nasional ${ }^{16}$.

Prinsip cabotage berturut-turut diatur dalam undang-undang penerbangan Indonesia. Di dalam UU No. 15 Tahun 1992, Pasal 13 ayat (1) ketentuan ini menyatakan bahwa pesawat udara yang dapat digunakan di wilayah RI hanya pesawat udara Indonesia. Ayat (2) dan (3) pasal ini juga mengatur bahwa penggunaan pesawat udara sipil

14 Mieke Komar Kantaatmadja, Berbagai Masalah Hukum Udara dan Angkasa, CV Karya Remadja, Bandung, 1984. Hlm 3.

15 Ibid. Hlm 5.

16 K. Martono, Kamus Hukum dan Regulasi Penerbangan, PT RajaGrafindo Persada, Jakarta, 2007. Hlm. 420. 
asing oleh perusahaan angkutan udara asing dari dan ke atau melalui wilayah RI untuk kegiatan angkutan udara berjadwal luar negeri, hanya dapat dilakukan berdasarkan perjanjian bilateral atau multilateral, sedangkan yang tidak berjadwal harus mendapatkan izin khusus. Prinsip cabotage secara jelas diatur dalam Pasal 36 ayat (1) UU No. 15 Tahun 1992. Menurut pasal ini angkutan udara niaga yang melayani angkutan udara didalam negeri hanya dapat diusahakan oleh badan hukum Indonesia baik badan usaha milik Negara (BUMN), badan usaha milik swasta (BUMS) maupun koperasi yang telah mendapat izin dari Menteri Perhubungan. Pasal ini diperjelas dengan Pasal 16 PP Nomor 40 tahun 1995 yang menentukan bahwa kegiatan usaha angkutan udara niaga ${ }^{17}$ baik berjadwal maupun tidak berjadwal dapat dilakukan oleh: 1). Badan Usaha Milik Negara; 2). Badan Usaha Milik Swasta yang berbentuk badan hukum; atau 3). Koperasi, dan Pasal 12 Keputusan Menteri Perhubungan (Kepmenhub) Nomor 81 Tahun 2004 tentang Penyelenggaraan Angkutan Udara.

Sebelumnya, asas cabotage tidak diatur dengan jelas dalam Undang-Undang Penerbangan Nomor 83 Tahun 1958. Dalam pasal 2 UndangUndang Penerbangan Nomor 83 Tahun 1958 dinyatakan: “....dilarang melakukan penerbangan selain dengan pesawat udara yang mempunyai kebangsaan Indonesia......” Pasal ini jelas merupakan suatu ketentuan yang mendasari prinsip bahwa Indonesia mempunyai "complete and exclusive souvereignty", yakni kedaulatan penuh dan eksklusif dalam wilayah udaranya. Dikaitkan dengan Pasal 8 undang-undang yang sama yang berisi ketetapan bahwa angkutan udara dengan dengan memungut bayaran yang diselenggarakan di dalam wilayah Indonesia harus dengan konsesi Menteri Perhubungan, Pasal 11 ayat (1), tentang pendaftaran dan kebangsaan pesawat udara dan Pasal 12 ayat (1) tentang larangan untuk pendaftaran bagi pesawat udara milik bangsa asing di Indonesia, terlihat bahwa angkutan cabotage di Indonesia, yakni pesawat udara yang dimiliki oleh orang Indonesia atau badan hukum Indonesia. Pesawat udara asing dilarang digunakan di-wilay udara Indonesia terkectali- oleh pert sahaan penerbangan asing yang diberi izin atas dasar suatu perjanjian bilateral atau dengan suatu izin khusus dari pemerintah Indonesia (lazimnya untuk penerbangan tidak berjadwal).

Dalam UURI Nomor 1 Tahun 2009 sebagai pengganti UU RI Nomor 15 Tahun 1992 tentang Penerbangan, prinsip cabotage diatur dalam Pasal 84 yang menetapkan bahwa Angkutan udara niaga dalam negeri hanya dapat dilakukan oleh badan usaha angkutan udara nasional yang telah mendapat izin usaha angkutan udara niaga. Lebih lanjut prinsip ini ditegaskan dalam Pasal 85 yang mengatur bahwa angkutan udara niaga berjadwal dalam negeri hanya dapat dilakukan oleh badan usaha angkutan udara niaga nasional baik milik BUMN, BUMD maupun BUMS berbentuk perseroan terbatas (PT) yang telah mendapat ijin usaha angkutan udara niaga berjadwal. Berikut Pasal 85 selengkapnya:

Angkutan udara niaga berjadwal dalam negeri hanya dapat dilakukan oleh badan usaha angkutan udara nasional yang telah mendapat izin usaha angkutan udara niaga berjadwal.

Badan usaha angkutan udara niaga berjadwal sebagaimana dimaksud pada ayat (1) dalam keadaan tertentu dan bersifat sementara dapat melakukan kegiatan angkutan udara niaga tidak berjadwal setelah mendapat persetujuan dari Menteri.

Kegiatan angkutan udara niaga tidak berjadwal yang bersifat sementara sebagaimana dimaksud pada ayat (2) dapat dilakukan atas inisiatif instansi Pemerintah dan/atau atas permintaan badan usaha angkutan udara niaga nasional.

Kegiatan angkutan udara niaga tidak berjadwal yang dilaksanakan oleh badan usaha angkutan udara niaga berjadwal sebagaimana dimaksud pada ayat (2) tidak menyebabkan terganggunya pelayanan pada rute yang menjadi tanggung jawabnya dan pada rute yang masih dilayani oleh badan usaha angkutan udara niaga berjadwal lainnya. 
Dalam rangka kebijakan liberalisasi, pertukaran hak-hak terbang ${ }^{18}$ (traffic right) secara multilateral dilakukan sejalan dengan konsep perdagangan bebas dunia yang terangkum dalam skema GATT (General Agreement on Trade and Tariff), dimana salah satu prinsipnya adalah "the Most-Favor Nation Treatment" atau asas resiprositas. Menurut H.K. Martono, kedepan pertukaran hak kebebasan udara ini akan berbentuk "aviation union of state”. Artinya hak-hak penerbangan akan dilakukan secara multilateral termasuk freedom ke delapan (cabotage). Sebagaimana prinsip "the Most-Favor Nation Treatment" atau asas resiprositas diatas, apabila Indonesia tidak melepaskan prinsip cabotage, Negara lain pun juga akan melakukan hal yang sama. Contohnya: apabila dunia penerbangan Eropa menjadi "aviation union of state”, Garuda Indonesia tidak dapat melakukan penerbangan dari Roma, di Italia ke Schippol di Belanda, karena rute tersebut merupakan cabotage Negara uni ${ }^{19}$.

Dalam menyikapi perkembangan dunia penerbangan kedepan, hendaknya Indonesia harus cukup berhati-hati, utamanya dalam rangka melindungi kepentingan nasional. Dengan kondisi penerbangan Indonesia saat ini, nampaknya tidak perlu bergegas mengikuti konsep liberalisasi secara utuh. Hal tersebut akan memberikan kondisi yang lebih buruk ditengah ketidakmampuan perusahaan penerbangan nasional untuk bersaing dengan perusahaan asing yang beroperasi di Indonesia.

\section{Pengaturan Prinsip Cabotage dalam ASEAN Multilateral Agreement on Air Services (ASEAN MAAS)}

ASEAN Open Sky Policy yang diatur dalam ASEAN Multilateral Agreement on Air Services (ASEAN MAAS), menentukan bahwa "the eight freedom" tidak dipertukarkan dan hanya menukarkan hak angkut ke-3, ke-4, dan ke-5. Liberalisasi hak angkut ke-3, ke-4 dan ke-5 dilakukan secara bertahap sesuai dengan ketentuan dalam protokol-protokol yang ada dalam kedua ASEAN Multilateral Agreement tersebut sampai dengan tahun 2015. Hal ini sesuai dengan kebijakan angkutan udara luar negeri Indonesia yang menetapkan bahwa open sky dilakukan secara selektif dan bertahap dengan memperhatikan kemampuan perusahaan penerbangan nasional. ${ }^{20}$

Mengenai kekebasan di udara yang diperjanjikan dalam ASEAN MAAS diatur dalam Pasal 2 ayat (1) yang menentukan bahwa setiap negara peserta haruslah mengakui hak-hak berikut ini dalam melaksanakan transportasi udara internasional :

hak penerbangan melintasi teritorial suatu negara tanpa landing;

hak melakukan penghentian di teritorial suatu negara bukan untuk tujuan traffic;

hak khusus yang dikecualikan dalam kesepakatan ini.

Seperti yang telah dejelaskan sebelumnya bahwa dalam ASEAN Multilateral Agreement on Air Services hanya memperjanjikan kebebasan hak angkut ke-3, ke-4 dan ke-5. Liberalisasi hak angkut ke-3, ke-4 dan ke-5 dilakukan secara bertahap sesuai dengan ketentuan dalam protokolprotokol yang ada dalam kedua ASEAN Multilateral Agreement tersebut sampai dengan tahun 2015.

Annex II dalam ASEAN Multilateral Agreement on Air Services tentang Implementing Protocol menetapkan bahwa negara ASEAN terikat pula kepada protokol-protokol yang menjadi bagian integral dari kesepakatan ASEAN Multilateral Agreement on Air Services. Protokolprotokol tersebut adalah :

Protocol 1 Unlimited Third and Fourth Freedom Traffics Within ASEAN Sub-region: Protokol ini memberikan kebebasan hak angkut ke-3 dan ke-4 di antara negara dalam ASEAN Sub-Region.

18 Sebenarnya secara teoritis terdapat delapan (eigth freedom of the air) kebebasan udara. Akan tetapi pada prakteknya hanya terdapat lima hak kebebasan udara (the five freedom in the air), yakni: The previlege to fly across its territory without landing; The previlege to land for non-traffic pusposes; The previlege to put down passengers, mail or cargo taken on in the territory of the state whose nationality the aircraft possesses; The previlege to take on passengers, mail or cargo destined for the territory of the state whose nationality the aircraft possesses; The previlege to take on passengers, mail or cargo destined for the territory of any other contracting state and the previlege to put down passengers, mail and cargo coming fram any such territory.

19 H.K. Martono, Hukum Angkutan Udara: Berdasarkan UU RI Tahun 2009 tentang Penerbangan, PT. Raja Grafindo Persada, Jakarta, 2010. Hlm. 52.

20 Adi Kusumaningrum, Pengaturan Pengamanan Sektor Angkutan Udara Indonesia Dalam Menghadapi ASEAN Single Aviation Market 2015, Tesis tidak diterbitkan, Malang, Fakultas Hukum Universitas Brawijaya, 2006, hlm 142 
Protocol 2 Unlimited Fifth Freedom Traffic Rights Within ASEAN Sub-Region: Protokol ini memberikan kebebasan hak angkut ke-5 di antara negara dalam ASEAN Sub-Region .

Protocol 3 Unlimited Third and Fourth Freedom Traffic Rights Between ASEAN SubRegions: Protokol ini memberikan kebebasan hak angkut ke-3 dan ke-4 di antara negara ASEAN yang berbeda Sub-Region.

Protocol 4 Unlimited Fifth Freedom Traffic Rights Between ASEAN Sub-Regions: Protokol ini memberikan kebebasan hak angkut ke-5 di antara negara ASEAN yang berbeda Sub-Region.

Protocol 5 Unlimited Third and Fourth Freedom Traffic Rights Between ASEAN Capital Cities: Protokol ini memberikan kebebasan hak angkut ke-3 dan ke-4 di antara ibu kota negaranegara ASEAN.

Protocol 6 Unlimited Fifth Freedom Traffic Rights Between ASEAN Capital Cities: Protokol ini memberikan kebebasan hak angkut ke-5 di antara ibu kota negara-negara ASEAN.

Sedangkan dalam Annex II yang terdapat pada ASEAN Multilateral Agreement on the Full Liberalisation of Passanger Air Services terdapat 2 (dua) protokol tambahan yang mengatur petahapan pelaksanaan liberalisasi angkutan udara penumpang yakni :

Protokol 1 Unlimited Third and Fourth Freedom Traffic Rights Between Any ASEAN Cities: di dalam protokol ini memberikan kebebasan hak angkut ke-3 dan ke-4 di antara setiap kota di ASEAN.

Protokol 2 Unlimited Fifth Freedom Traffic Rights Between Any ASEAN Cities: di dalam protokol ini memberikan kebebasan hak angkut ke-5 di antara setiap kota di ASEAN.

Prinsip kedaulatan atas wilayah udara secara penuh dan utuh ini juga diakui dalam Asean Multilateral Agreement on Air Services dengan ketentuan Pasal 1 ayat (1) yang menyatakan bahwa negara-negara peserta agreement telah meratifikasi Konvensi Chicago 1994 dan konvensi tersebut masih berlaku secara efektif bagi mereka.

Prinsip cabotage ditegaskan dalam pasal 2 ayat (3) ASEAN Multilateral Agreement on Air Services (ASEAN MAAS) yang berbunyi :

Nothing in this Agreement shall be deemed to confer on the airline or airlines of one Contracting Party the right to take on board, in the territory of another Contracting Party, passangers, baggage, cargo, or mail carried for remuneration and destined for another point in the territory of that other Contracting Party.

Pasal tersebut menetapkan bahwa tidak ada ketentuan dalam ASEAN Multilateral Agreement on Air Services yang bisa diinterpretasikan sebagai ketentuan yang memberi hak bagi setiap pesawat udara milik negara peserta untuk mengangkut penumpang, bagasi, barang ataupun pos dengan mendapatkan bayaran dan dengan tujuan dari suatu tempat ke tempat lainnya di dalam wilayah teritorial negara peserta lainnya.

Hak cabotage merupakan hak penuh masingmasing perusahaan penerbangan. Suatu negara bebas untuk menetapkan larangan traffic cabotage dalam wilayahnya bagi perusahaan penerbangan asing. Sampai dengan saat ini, meskipun liberalisasi jasa angkutan udara banyak dijajaki negaranegara di dunia untuk segera dilakukan, menurut penulis hak ini masih akan tetap dipertahankan oleh masing-masing negara di dunia. Amerika Serikat dalam Federal Aviation Act 1958 Section 1108 (b) dengan tegas melarang angkutan cabotage oleh suatu pengangkutan asing. Apabila suatu pesawat udara asing sedang melakukan continuous voyage, maka mengangkut dan menurunkan traffic pada dua titik (tempat) di dalam wilayah Amerika (foreign transfer traffic) diartikan sebagai cabotage yang tidak dapat diizinkan.

\section{Pengaturan Pendaftaran Pesawat dan Investasi di Bidang Angkutan Udara}

Sebagaimana diuraukan, prinsip cabotage merupakan hak prerogatif/istimewa Negara berdaulat yang diakui didalam Pasal 7 Konvensi Chicago 1944. Menurut pasal ini setiap Negara berhak menolak pemberian izin pesawat udara asing yang melakukan angkutan penumpang, barang, dan pos secara komersial dalam negeri. Hak angkutan udara niaga dalam negeri diberikan kepada perusahaan penerbangan nasional, dan tidak akan diberikan kepada perusahaan asing mana pun, kecuali atas pertimbangan untuk kepentingan nasional Negara yang bersangkutan.

Kebijakan open sky yang akan membentuk ASEAN Single Aviation Market 2015, tantangan bagi industry angkutan udara di Indonesia cukup tinggi. Seiring dengan berkembangnya Low Cost Carrier/LCC pada angkutan udara, Indonesia 
dibanjiri investasi dari maskapai-maskapai asing, diantaranya adalah Air Asia (Malaysia) dan Silkair (Singapura). Kedua investasi asing tersebut juga membuka rute-rute dalam negeri. Tidak saja Indonesia Air Asia, silkair baru-baru ini juga mempunyai rute dalam negeri, seperti: rute penerbangan yang biasanya direct Singapura-Denpasar (Bali), dirubah menjadi Denpasar-Singapura melalui Bandara Internasional Lombok. ${ }^{21}$

Kedua investasi asing angkutan udara tersebut diatas dimungkinkan dengan adanya pengaturan dibidang investasi melalui Undang-Undang Nomor 25 Tahun 2007 tentang Penanaman Modal. Mengacu pada ketentuan Pasal 1 ayat (3) yang terdapat dalam UU Penanaman Modal No. 25 Tahun 2007, maka yang disebut sebagai "Penanaman Modal Asing”, harus memenuhi beberapa unsur berikut:

Merupakan kegiatan menanam modal,

Untuk melakukan usaha di wilayah negara Republik Indonesia,

Dilakukan oleh penanam modal asing,

Menggunakan modal asing sepenuhnya maupun yang berpatungan dengan penanam modal dalam negeri.

Di Indonesia dalam rangka memberikan perlindungan hukum penanaman modal asing wajib berbentuk perseroan terbatas (PT) berdasarkan hukum Indonesia dan berkedudukan di wilayah negera RI (pasal 5 ayat 2, UU No.25 tahun 2007). Dengan kata lain penanaman modal asing tidak di izinkan melakukan usaha sebelum terbentuknya badan hukum Indonesia. Demikian halnya dengan penanaman modal asing dibidang angkutan udara juga harus berbentuk badan hukum Indonesia. Selanjutnya dalam Pasal 25 UURI Nomor 1 Tahun 2009 ditentukan bahwa:

Pesawat udara sipil yang dapat didaftarkan di Indonesia harus memenuhi ketentuan sebagai berikut:

tidak terdaftar di negara lain; dan dimiliki oleh warga negara Indonesia atau dimiliki oleh badan hukum Indonesia;

dimiliki oleh warga negara asing atau badan hukum asing dan dioperasikan oleh warga negara Indonesia atau badan hukum Indonesia untuk jangka waktu pemakaiannya minimal 2 (dua) tahun secara terus-menerus berdasarkan suatu perjanjian; dimiliki oleh instansi pemerintah atau pemerintah daerah, dan pesawat udara tersebut tidak dipergunakan untuk misi penegakan hukum; atau

dimiliki oleh warga negara asing atau badan hukum asing yang pesawat udaranya dikuasai oleh badan hukum Indonesia berdasarkan suatu perjanjian yang tunduk pada hukum yang disepakati para pihak untuk kegiatan penyimpanan, penyewaan, dan/atau perdagangan pesawat udara.

Sedangkan untuk masalah komposisi kemilikan modal diatur dalam Pasal 108 UURI Nomor 1 Tahun 2009, yang selengkapnya berbunyi:

Kegiatan angkutan udara niaga sebagaimana dimaksud dalam Pasal 83 ayat (1) huruf a dilakukan oleh badan usaha di bidang angkutan udara niaga nasional.

Badan usaha angkutan udara niaga nasional sebagaimana dimaksud pada ayat (1), seluruh atau sebagian besar modalnya, harus dimiliki oleh badan hukum Indonesia atau warga negara Indonesia.

Dalam hal modal badan usaha angkutan udara niaga nasional yang dimiliki oleh badan hukum Indonesia atau warga negara Indonesia sebagaimana dimaksud pada ayat (2) dibagi-bagi, salah satu pemegang modal nasional harus tetap lebih besar dari pemegang modal asing (single majority).

Ketentuan dalam Pasal 108 tersebut diatas mengatur tentang adanya kewajiban single majority atas kepemilikan modal oleh badan hukum atau warga Negara Indonesia. Sesuai dengan ketentuan penanaman modal asing di Indonesia, 51 \% saham harus dimiliki oleh badan hukum atau warga Negara Indonesia. Ketentuan ini juga mengatur tentang kewajiban menyetor modal, namun demikian tidak ditentukan prosentase modal yang harus disetorkan.

Meskipun demikian, lemahnya pengawasan (direct or indirect) investment bidang angkutan udara, akan memberikan kemungkinan terjadi penyelundupan hukum investasi, yang akhirnya pasar nasional tetap saja akan dikuasai asing melalui badan hukum Indonesia yang dibentuknya (cabotage terselubung). Bagaimanapun keikutsertaan PMA ini merupakan masalah tersendiri bagi penegakkan prinsip cabotage, karena dalam kenyataannya tidak tertutup kemungkinan di atas kertas sahamnya memang 51 \% Indonesia dan 49 
$\%$ asing, tetapi yang berkuasa dalam menentukan kebijakan tetap saja perusahaan yang minoritas (asing). Baik secara filosofis maupun historis, prinsip cabotage diterapkan secara umum di seluruh dunia dengan tujuan menjaga dan melindungi kepentingan politik dan ekonomi negara yang bersangkutan. Penerapan prinsip cabotage secara operasional bisa bersifat fleksibel, selama kepentingan strategis negara tersebut tetap terjaga dan terlindungi.

\section{Kesimpulan}

Secara normatif peraturan perundangundangan di Indonesia telah mengatur prinsip cabotage, baik dalam UU RI Nomor 1 Tahun 2009 tentang Penerbangan maupun dalam UndangUndang Nomor 25 Tahun 2007 tentang Penanaman Modal. Kedua undang-undang tersebut mengatur adanya kewajiban single majority atas kepemilikan modal oleh badan hukum atau warga Negara Indonesia, termasuk dalam industry pener-

\section{DAFTAR PUSTAKA}

Cheng, Bin, 1962, The Law of International Air

Transport, London: The London Institute of World Affairs.

Churchill, R.R., dan Lowe, A.V., The Law of The

Sea, third Edition, Manchester: Manchester University Press.

Komar Kantaatmadja,Mieke, 1984, Berbagai

Masalah Hukum Udara dan Angkasa, CV Karya Remadja, Bandung.

Martono, K., 2007, Kamus Hukum dan Regulasi

Penerbangan, PT RajaGrafindo Persada, Jakarta.

Martono, H.K., 2010, Hukum Angkutan Udara: Berdasarkan UU RI Tahun 2009 tentang Penerbangan, PT. RajaGrafindo Persada, Jakarta.

Rudy, T. May, 2002, Hukum Internasional 2, Bandung: PT Refika Aditama.

\section{Karya Ilmiah}

Adi Kusumaningrum, 2006, Pengaturan Pengamanan Sektor Angkutan Udara Indonesia Dalam Menghadapi ASEAN Single Aviation Market 2015, Tesis tidak diterbitkan, Malang, Fakultas Hukum Universitas Brawijaya. bangan. Meskipun demikian, pengawasan dalam penerapan hukumnya harus dilakukan secara ketat, jangan sampai status badan hukum Indonesia hanya merupakan suatu kepentingan terselubung saja sedangkan seluruh kebijakan diambil oleh bangsa asing yang menguasai perusahaan tersebut. Penegakkan hukum investasi juga diperlukan agar status badan hukum Indonesia tidak hanya digunakan untuk mengambil pangsa pasar industri angkutan udara Indonesia yang sangat potensial. Dalam memberikan perlindungan terhadap kepentingan nasional Indonesia terhadap dunia penerbangan/angkutan udara, utamanya penegakkan prinsip cabotage, hendaknya pemerintah dalam memberikan ijin harus benar-benar sesuai dengan ketentuan yang berlaku. Pemberian ijin suatu maskapai penerbangan tersebut yang juga berhubungan dengan kebijakan penetapan layanan rute penerbangan antar wilayah dari satu daerah ke daerah lain dalam wilayah negara Indonesia harus didasarkan pada kesejahteraan bagi masyarakat Indonesia pada umumnya.

\section{Peraturan Perundangan-Undangan}

Undang-Undang Nomor 1 Tahun 2009 tentang Penerbangan

Undang-Undang Nomor 25 Tahun 2007 tentang Penanaman Modal International Air Transport Agreement, Chicago 1944 ASEAN Multilateral Agreement on Air Services (ASEAN MAAS)

\section{Internet}

Penerbangan RI Diminta Terapkan Asas Cabotage, http://www.inilah.com/read/ detail/1646272/penerbangan-ri-dimintaterapkan-asas-cabotage.

Kebijakan Open Sky di Indonesia, DPR minta pemerintah buat cabotage versi udara untuk tangkis open sky, http://nasional. kontan.co.id/news/dpr-minta-pemerintahbuat-cabotage-versi-udara-untuk-tangkisopen-sky-1/2011/06/27.

h t t p : / / edukasi.kompas.com/ $\mathrm{read} / 2011 / 11 / 24 / 16344968 / S i l k . A i r$. Tambah.Penerbangan.Rute.SingapuraLombok 